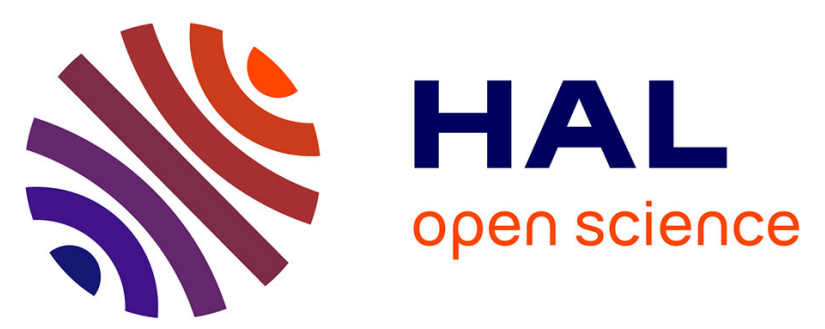

\title{
Evaluation and comparison of size-density relationships for pure even-aged stands of ash (Fraxinus excelsior L.), beech (Fagus silvatica L.), oak (Quercus petraea Liebl.), and sycamore maple (Acer pseudoplatanus L.)
}

\author{
Le Goff, Ottorini, Ningre
}

\section{To cite this version:}

Le Goff, Ottorini, Ningre. Evaluation and comparison of size-density relationships for pure evenaged stands of ash (Fraxinus excelsior L.), beech (Fagus silvatica L.), oak (Quercus petraea Liebl.), and sycamore maple (Acer pseudoplatanus L.). Annals of Forest Science, 2011, 68 (3), pp.461-475. 10.1007/s13595-011-0052-8 . hal-00930787

\section{HAL Id: hal-00930787 https://hal.science/hal-00930787}

Submitted on 1 Jan 2011

HAL is a multi-disciplinary open access archive for the deposit and dissemination of scientific research documents, whether they are published or not. The documents may come from teaching and research institutions in France or abroad, or from public or private research centers.
L'archive ouverte pluridisciplinaire HAL, est destinée au dépôt et à la diffusion de documents scientifiques de niveau recherche, publiés ou non, émanant des établissements d'enseignement et de recherche français ou étrangers, des laboratoires publics ou privés. 


\title{
Evaluation and comparison of size-density relationships for pure even-aged stands of ash (Fraxinus excelsior L.), beech (Fagus silvatica L.), oak (Quercus petraea Liebl.), and sycamore maple (Acer pseudoplatanus L.)
}

\author{
Noël Le Goff • Jean-Marc Ottorini • François Ningre
}

Received: 6 May 2010 /Accepted: 22 October 2010/Published online: 3 May 2011

(C) INRA and Springer Science+Business Media B.V. 2011

\begin{abstract}
- Introduction Size-density relationships define the maximum number of stems that even-aged stands of a given species can hold in relation to the mean size of trees. They are used to derive stand density measures and are useful tools used to control tree mortality.

- Objectives Size-density relationships were already available in France for beech and oak. The objective of this study was to extend these relations to younger development stages and test if specific relations are needed to be established for a set of species of different shade tolerance, including beech, ash, sycamore maple, and oak.

- Results We relied on stands growing at maximum density and used selected data coming from the inventories of permanent control plots and specifically established temporary plots. A multiple comparison procedure was used to differentiate between the parameters of the relations. Two size-density relations were retained with a common slope and different intercepts for ash and beech on one hand, and for oak and sycamore maple on the other hand. Stands of shade-intolerant species like oak appeared able to hold less trees of a given mean size, but shade tolerance did not seem to influence the mortality rate which appeared to be the same.
\end{abstract}

\section{Handling Editor: Matthias Dobbertin}

Electronic supplementary material The online version of this article (doi:10.1007/s13595-011-0052-8) contains supplementary material, which is available to authorized users.

N. Le Goff $(\bowtie) \cdot$ J.-M. Ottorini $\cdot$ F. Ningre

INRA, AgroParisTech, UMR 1092, LERFoB,

Centre INRA de Nancy,

54280 Champenoux, France

e-mail: le_goff@nancy.inra.fr
Keywords Self-thinning line - Size-density relation . Multistage data analysis $\cdot$ Mixed effects model .

Multiple comparisons

\section{Introduction}

This study takes place in a larger research program intended to develop a stand growth simulator, on an individual tree basis, for even-aged stands of beech, ash, and sycamore maple, pure or mixed. In tree growth simulators, mortality needs to be precisely predicted as it determines the natural stand dynamics - density and growth of living stemsespecially in early stages and when stands are not heavily treated with thinnings.

Tree mortality functions, at tree or stand levels, are difficult to establish as they need to have inventories of trees over a long period for stands maintained without any intervention, so as they can evolve at a maximum density. Size-density relationships give an alternative to control tree mortality in simulated even-aged stands (Yang and Titus 2002; Monserud et al. 2005): a stand of a given species with a given mean size cannot present a larger number of stems than the number predicted by the size-density relationship. This allows, in a stand growth simulator, to remove artificially the stems "in excess" in the predicted stand, for example the smaller trees which are generally over-topped and more prone to die (Dhôte 1996).

Size-density relationships can give a limit for maximum stand density and also lead to a trajectory to reach this limit. These two concepts of the size-density relationships were first defined by Weller (1987) and adopted by other authors (Puettmann et al. 1993; Bégin et al. 2001; Pretzsch 2006). While considering the whole size-density trajectory, and not only the maximum size-density line, may be advantageous to 
establish size-density relations, particularly because it avoids the problem of selecting stands that are at maximum density (Puettmann et al. 1993; Vanclay and Sands 2009), it would need however to have enough data from unthinned stands observed on a large time span, which could only be met for old studied species (like beech in our case). Then, this study will only consider the concept of the maximum size-density line - also called self-thinning line - the trajectories to reach the self-thinning line being the subject of a complementary study.

As stated before, establishing the self-thinning line needs to rely on data coming from stands that are actually in a true self-thinning mode (Shaw 2006). Methods which are insensitive to understocked conditions have been developed (Zhang et al. 2005) but are not suitable when we can rely, even partially, on control plots established in stands at maximum density and observed over a long period. When not relying on these methods, processes of data selection need to be defined to retain only data corresponding to stands at maximum density.

Generally, the size-density relationship (self-thinning line) appears, for a given species, as a linear relation linking the maximum number $\left(N_{\max }\right)$ of living stems of a stand to their mean diameter $(\mathrm{Dg})$ or girth $(\mathrm{Cg})$ at breast height, in $\log -\log$ scales, although mean diameter or girth can be replaced by mean volume or biomass (Smith and Hann 1984; Bégin et al. 2001; Pretzsch 2006). This relation goes back to the work of Reineke (1933) who stated the "stand density rule" as $N_{\max }=\alpha \operatorname{Dg}^{\beta}$ or $\ln N_{\max }=\ln \alpha+\beta \ln \mathrm{Dg}$ in which $\beta$ is a constant (equal to -1.605 ) and is independent of species, age, and site quality while $\alpha$ varies with species (White and Harper 1970). This constancy of $\beta$ has however been invalidated by various studies among which Puettmann et al. (1993) and more recently Pretzsch (2006); these studies revealed significant differences of $\beta$ between species. The variability with species of the $\beta$ parameter in Reineke's equation was investigated in this study by adding sessile oak, a shade-intolerant species, to the three species first selected (ash, beech, and sycamore maple) allowing to explore a large range of shade tolerance (Perrin 1963).

Significant differences in maximum stand density may appear, for a given species, related to different yield levels which can be observed for stands of same site index (Hasenauer et al. 1994), although site index itself does not seem to be able to explain such differences (Schütz and Zingg 2010). The variations of maximum density with yield level could be related to genetic or environmental differences, and possibly be revealed through "regional" differences (Hasenauer et al. 1994).

Size-density relationships are used to derive stand density measures - the well-known relative density index (RDI) or SDI indexes-which can either be incorporated in tree and stand growth models (Smith and Hann 1986; Le Goff and Ottorini 1999; Pretzsch 2005) or in stand density management diagrams (Drew and Flewelling 1979; Hibbs 1987; Sales Luis and Fonseca 2004; Shaw 2006). Then, the parameters of the size-density relationships need to be precisely estimated for each species.

In a preceding study, we were able to establish a sizedensity relationship for beech in France (Le Goff and Ottorini 1999), thanks to the data collected since the early 1900 s in the control plots of permanent thinning trials located in naturally regenerated stands in the north-east of France:

$\ln \left(N_{\max }\right)=14.0367-1.666 \ln (C g)$

where $N_{\max }$ is calculated for 1 ha and $\mathrm{Cg}$ is in centimeters and where "ln" stands for the natural logarithm.

However, it must be noticed that young stands with $\mathrm{Cg}<25 \mathrm{~cm}$ were rare and even totally missing for $\mathrm{Cg}<$ $15 \mathrm{~cm}$, in the beech thinning network used to build this relation.

A size-density relation was also established for oak (Dhôte 1997), based on data from permanent plots, but comprising few control plots and, as for beech, rare young stands; in this case, the relation was obtained as the above limit of the data set and partly hand-drawn. For ash and sycamore, no relation was available, and very few data from permanent plots existed, as these species are of recent interest for foresters.

The size-density equation already established for beech gives the maximum density that, on average, beech stands can maintain. Individual beech stands may fall above or below the maximum size-density line (Puettmann et al. 1993), as it is the case for the observed data from different control plots. This way of considering the size-density equation was retained for the present study for the different species considered, even if observational data were not all issued from permanent control plots, in order to make comparisons between species possible. It differs from considering the size-density equation as the upper limit or "frontier" of a data distribution obtained without selection and covering a large range of density conditions (Zhang et al. 2005).

The objective of this study was then (1) to revise the size-density relations already established for beech and oak, using new data from plots at maximum density, especially in the younger stages, (2) to establish sizedensity relationships for ash and sycamore, and (3) to compare the different relations established for ash, beech, oak, and sycamore and examine if a common sizedensity relationship can be retained for some of the species under study. 


\section{Materials and methods}

\subsection{Data}

The data to be used for size-density relationships establishment should come from even-aged and mostly pure stands (from natural or artificial origin), fully stocked, unthinned, and considered at maximum density. The objective was then to select data corresponding to plots undergoing self-thinning process and as close as possible to the presumed self-thinning line. Rather than following the "interval method" to select data (Bi and Turvey 1997) which presents some drawbacks (Zhang et al. 2005), we preferred to rely on justified criteria showing that sample stands were evolving at maximum density ${ }^{1}$ (Rio et al. 2001). These selection criteria depend on the origin of the data for each species; they will be specified subsequently for each data set retained.

\subsubsection{Beech}

New data from various experiments were obtained. They included young stages of development which were missing in the previous relation established:

- a beech experimental plantation installed in the Spring of 1981 in the State forest of Lyons-La-Forêt (NW of France) with different initial planting densities (625 to 40,000 trees per hectare) and re-measured regularly (Ningre and Colin 2007): only the two last inventories (1995 and 2004) of the unthinned plots were considered for the study;

- an experiment installed in 1995 in a 12-year-old natural regeneration in the State forest of Moyeuvre (NE France) comparing pure and mixed plots of beech, ash and sycamore at two density levels: small circular inventory plots of the highest density level installed and measured by $\mathrm{ONF}^{2}$ and containing more than $80 \%$ of beech were selected, and only the two last inventories (1998 and 2002) were considered for the study because they were far enough from the time of thinning trails opening in the regeneration;

- temporary plots established in artificial regenerations of beech in Normandy (NW France) (Falcone 1985); and

- an unthinned plot installed in 1991 in a naturally regenerated 35-year-old stand in the State forest of Souilly (NE France), referred to as Souilly "QB"; it was the control part of a pruning experiment. Only the

\footnotetext{
${ }^{1}$ In fact, in French broadleaved high forests, the naturally regenerated stands are managed more or less intensively, and then stands are rarely at maximum density, even in the young stages.

${ }^{2}$ ONF: French National Forest Service
}

inventory at installation was considered as the plot was subsequently thinned.

Additional data coming from the control plots of the thinning trial of Souilly (NE France), referred to as "Carré Latin", already used for the previous relation established for beech in 1999 (Le Goff and Ottorini), were also added to the data set; they correspond to the new inventories performed after 1994.

The previously fitted relation, extended to low values of $\mathrm{Cg}$, appeared as an upper tendency line for the new data set, even for young stages of development (Fig. 1). Moreover, among the plots that were re-measured the ones close to the line appeared to follow relatively well the originally fitted relation (same slope), while the ones more distant from the line showed a gentler slope indicating that these plots supported a lower mortality than stands at maximum density. Finally, only the data close to the line and comprised in the same boundaries as the ones used for the establishment of the previous relation, were considered for further analysis.

The additional data set for the re-evaluation of the sizedensity relation of beech appears in Table S1, together with the previously used data set.

\subsubsection{Oak}

Data from experimental plots of different origins were collected, coming at the same time from unthinned plots (control) and from thinned plots before they were thinned. In each case, selection criteria were defined to make sure that the plots were at maximum density for the inventory years retained:

- an oak experimental plantation installed in the Spring of 1981 in the State forest of Lyons-La-Forêt (NW of France) comprising plots with different initial planting densities (1,333 to 5,333 trees per hectare) replicated four times and two sawn plots at a density of 50 acorns per square meter (which corresponds to a theoretical density of 500,000 trees per hectare), all re-measured regularly. Only the two last inventories of the four plots at highest planting density (5,333 trees per hectare) were considered (years 2003 and 2006), together with the last inventories of the two sawn plots (from 1994 to 2006);

- two old control plots of thinning experiments installed in the State forests of Reno-Valdieu (NW France) and Blois (Center France), and three more recent ones installed in the State forest of Tronçais (Center France); these plots may have only been subjected to cleaning operations in the young stages not considered for this study;

- control plots more recently installed in the scope of the French forest network "GIS-Coop",3 in different regions

\footnotetext{
${ }^{3}$ GIS-Coop: "Groupement d'Intérêt Scientifique" called "Coopérative de données sur la croissance des peuplements forestiers"
} 

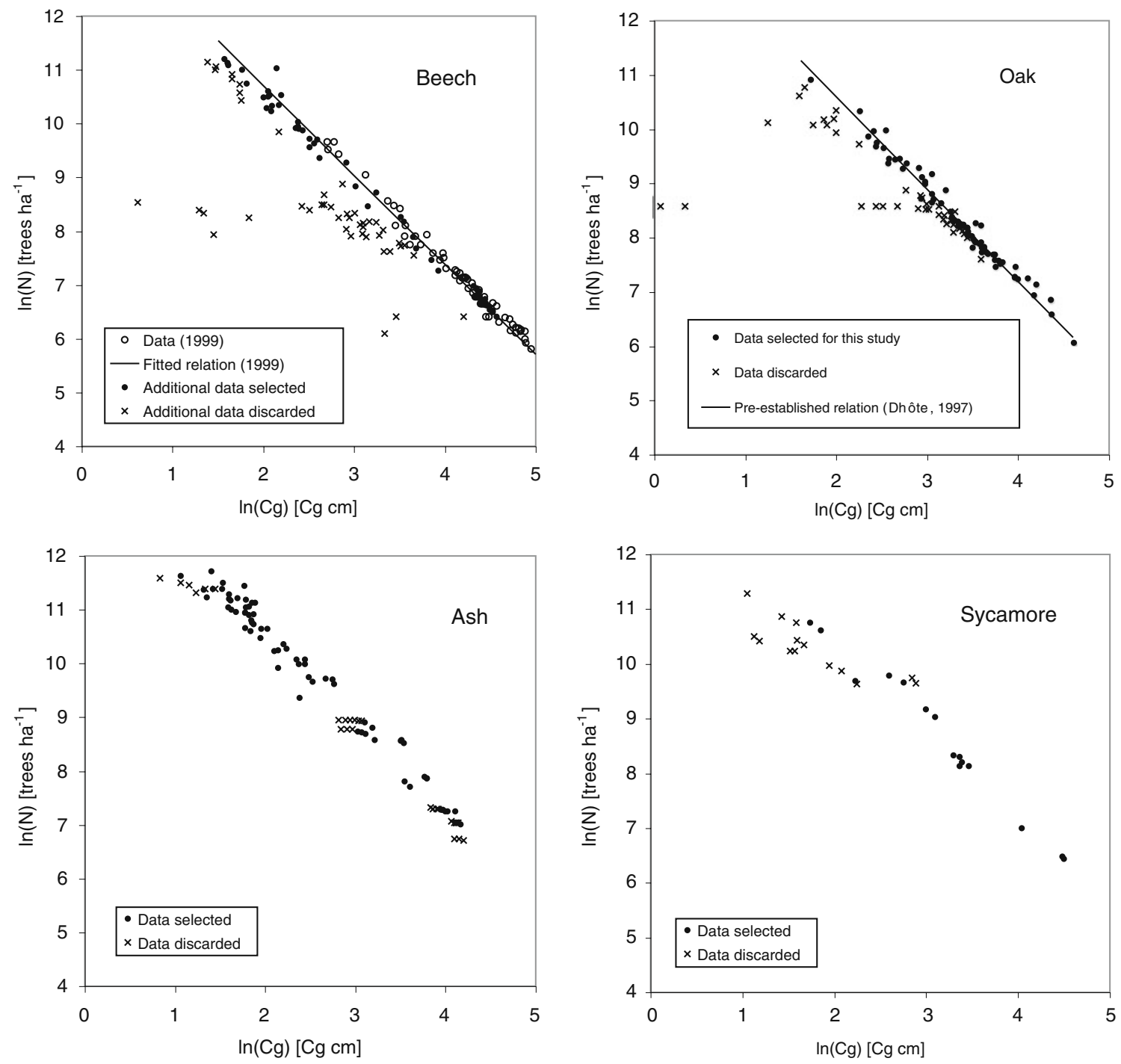

Fig. 1 Observed $(\mathrm{N}, \mathrm{Cg})$ data, in $\log -\log$ scales, for the temporary and permanent plots used to establish the size-density relations of beech, oak, ash, and sycamore. The data selected after a selection process ensuring that they come from stands at maximum density are

distinguished from those which were discarded. The previous sizedensity relations established for beech (Le Goff and Ottorini 1999) and for oak (Dhôte 1997) are also represented

of France; only the last inventories were selected to avoid the effects of cleaning operations and thinning trails performed in the young stages;

- control plots of ONF trials installed in young stands: the first inventory was omitted when corresponding to the date of installation and when cleaning and thinning trails were performed close to that date; and

- two temporary plots recently installed in plantations at high density located in Pays de Loire (NW France).

The characteristics of the plots considered for the reevaluation of the size-density relation of sessile oak appear in Table S2 according to their origin, with the selected inventories

for each plot. The corresponding $(\mathrm{Cg}, N)$ data, together with the previously established size-density relation (Dhôte 1997), are displayed in Fig. 1. The selected data for oak seem in good accordance with the previously established relation while the discarded ones issued from the unselected plot inventories, are, with few exceptions, situated below the line.

\subsubsection{Ash}

As mentioned before, data from pure even-aged stands of ash maintained at high densities are scarce. However, control plots of two recent INRA thinning trials in NE France already exhibiting mortality could be selected: 
Brouennes and Val-St-Pierre, installed, respectively, in 1996 and 1993. Moreover, temporary plots established in NE France, and eventually re-measured, were also used:

- plots established in 1982-1983 for site-productivity studies of ash in Alsace region (Nicot 1983) and presenting a high density level, measured at only one occasion;

- plots established in Lorraine region for studies on natural regeneration of ash (Duval 1987), also measured at only one occasion;

- small circular inventory plots of the highest density level treatment of the already cited Moyeuvre experiment, and containing more than $80 \%$ of ash (only last inventory of 2002 retained); and

- new plots in Lorraine region (Table 1), especially installed in dense natural regenerations presenting natural mortality, and inventoried at two or three dates (between 2005 and 2007). In this case, tree mortality was more precisely evaluated in order to judge the time since the self-thinning process could have started: we distinguished four categories of "dead trees" (trees lying on the soil and presumed to be dead several years ago; standing dead trees divided into formerly dead trees, trees dead recently (presumably since the last inventory) and currently dying trees, depending on the aspect of tree bark and resistance when pulling up the tree).

Without a pre-established relation like for oak or beech, a selection process was defined in order to retain data corresponding to maximum density. For re-measured temporary and permanent plots, data with an annual mortality rate ${ }^{4}$ less than $1 \%$ for two successive years were rejected. Generally, the temporary plots retained on this criterion presented also a high number of trees dead prior to the first inventory relatively to the number of living trees indicative of a well under way mortality process. The $(\mathrm{Cg}, N)$ data selected following this procedure were plotted on a graph (not shown) in a $\log -\log$ scale, with additional data coming from the older non-re-measured temporary plots in Lorraine and Alsace: among those, the data outside the limits of the scatterplot of the already retained data were rejected. The characteristics of the finally selected plots for ash appear in Table $\mathrm{S} 3$, and the corresponding $(\mathrm{Cg}, N)$ data are displayed in Fig. 1 in $\log -\log$ scales, together with the discarded data which generally are situated in the lower part

\footnotetext{
${ }^{4}$ The annual mortality rate was calculated as the ratio (in \%) of the number of trees dead in a one year interval between two successive inventories on the total number of trees (alive and dead) at the time of last inventory. In case of a first or unique inventory, the trees inventoried as "recently dead" were used to calculate this ratio, presuming that they were alive the year before the plot inventory and so died in a 1-year interval.
}

of the scatter diagram which corresponds to densities below maximum.

\subsubsection{Sycamore}

For sycamore, data from unthinned long-term permanent plots were not available. Then, the establishment of the size-density relationship for sycamore relied only on temporary plots recently installed in fully stocked stands with no sign of recent cleaning or thinning treatment and presenting natural mortality, in Lorraine and Alsace regions (NE France); these plots were generally inventoried at two dates (2006 and 2007). The characteristics of the sampled plots appear in Table 2. As for the new temporary plots of ash established, dead trees in sycamore plots were inventoried, using the same classification to sort dead trees by "age" class.

In the sample plots, sycamore trees appeared often mixed with other tree species (ash, beech, etc.) and may be also over-topped by an upper layer of older trees (Table 2) reducing significantly the transmitted radiation. Selection criteria were then defined to ensure homogeneous growing conditions for sycamore, in addition to the minimum mortality of $1 \%$ already retained for ash: sycamore trees must represent more than $80 \%$ of the stand, in terms of number of stems and basal area, and must not be completely covered by an upper layer. Moreover, the data from plot 5 of "Matstall" in 2007 were discarded, an over-topping tree being removed at the end of 2006. The data finally selected for sycamore appear in Table $\mathrm{S} 4$, and the corresponding $(\mathrm{Cg}, N)$ data are displayed in Fig. 1 in $\log -\log$ scales, together with the discarded data which generally are situated in the lower part of the scatter diagram (as for the other species), except for two points corresponding to a plot with a high mixture of beech.

The geographical distribution of the selected plots for each species appear in Fig. 2. The plots are located in northern France between $1^{\circ} 35^{\prime} 2^{\prime \prime} \mathrm{W}-7^{\circ} 58^{\prime} 44^{\prime \prime}$ E longitude and $46^{\circ} 30^{\prime} 8^{\prime \prime} \mathrm{N}-49^{\circ} 52^{\prime} 39^{\prime \prime} \mathrm{N}$ latitude.

\subsection{Data analysis}

For each sample plot and inventory year retained, the following stand characteristics were obtained: age, number of living trees $\left(N\right.$, trees ha $\left.{ }^{-1}\right)$, basal area $\left(G, \mathrm{~m}^{2} \mathrm{ha}^{-1}\right)$, and mean girth at breast height $(\mathrm{Cg}, \mathrm{cm})$ of living trees. Mean stand height was not available for all inventory years and plots and then could not be tested as a possible significant variable in the size-density equation as some authors could have done (Zeide 1995; Rio et al. 2001).

The model of Reineke (1933) already successfully fitted to beech data from control plots (Le Goff and Ottorini 


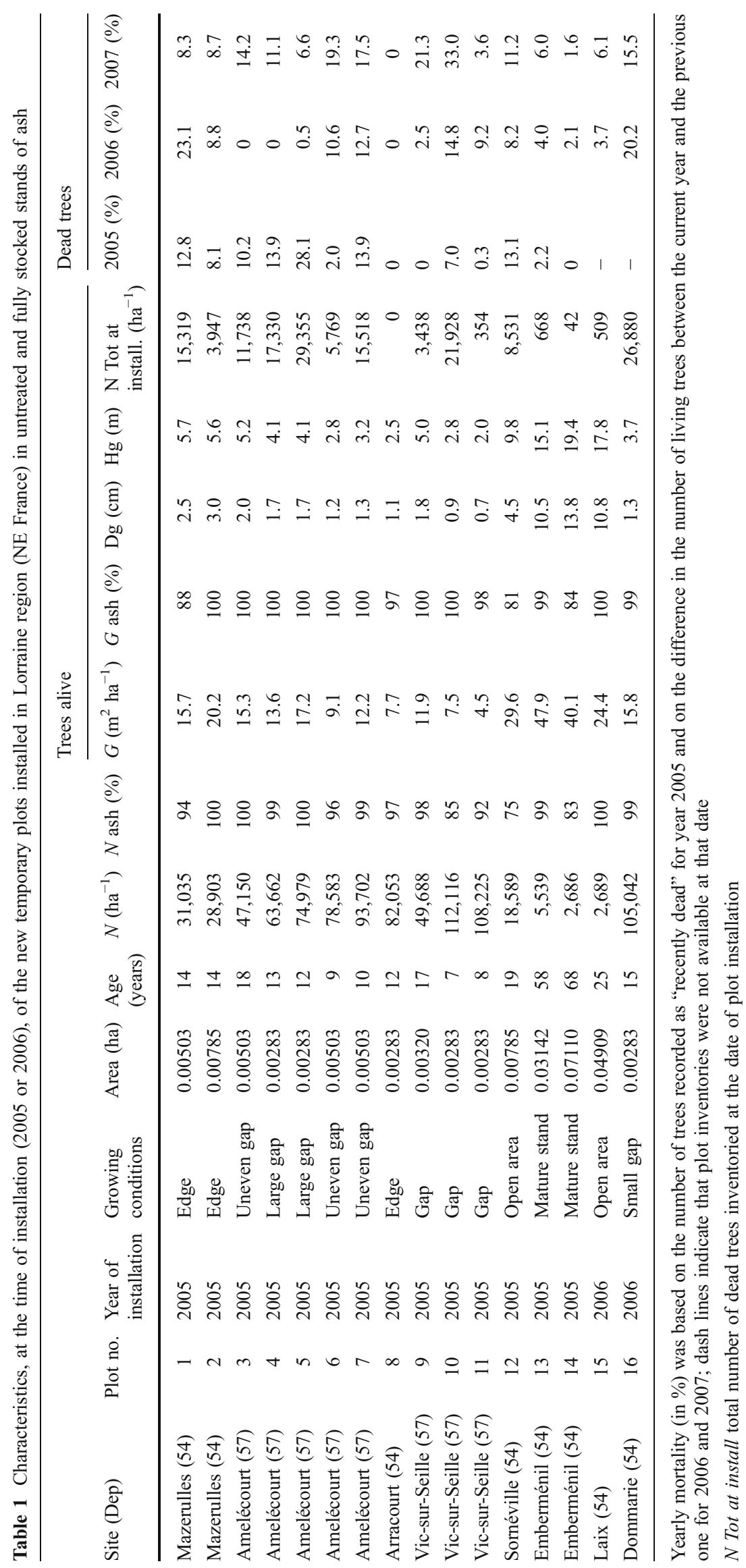




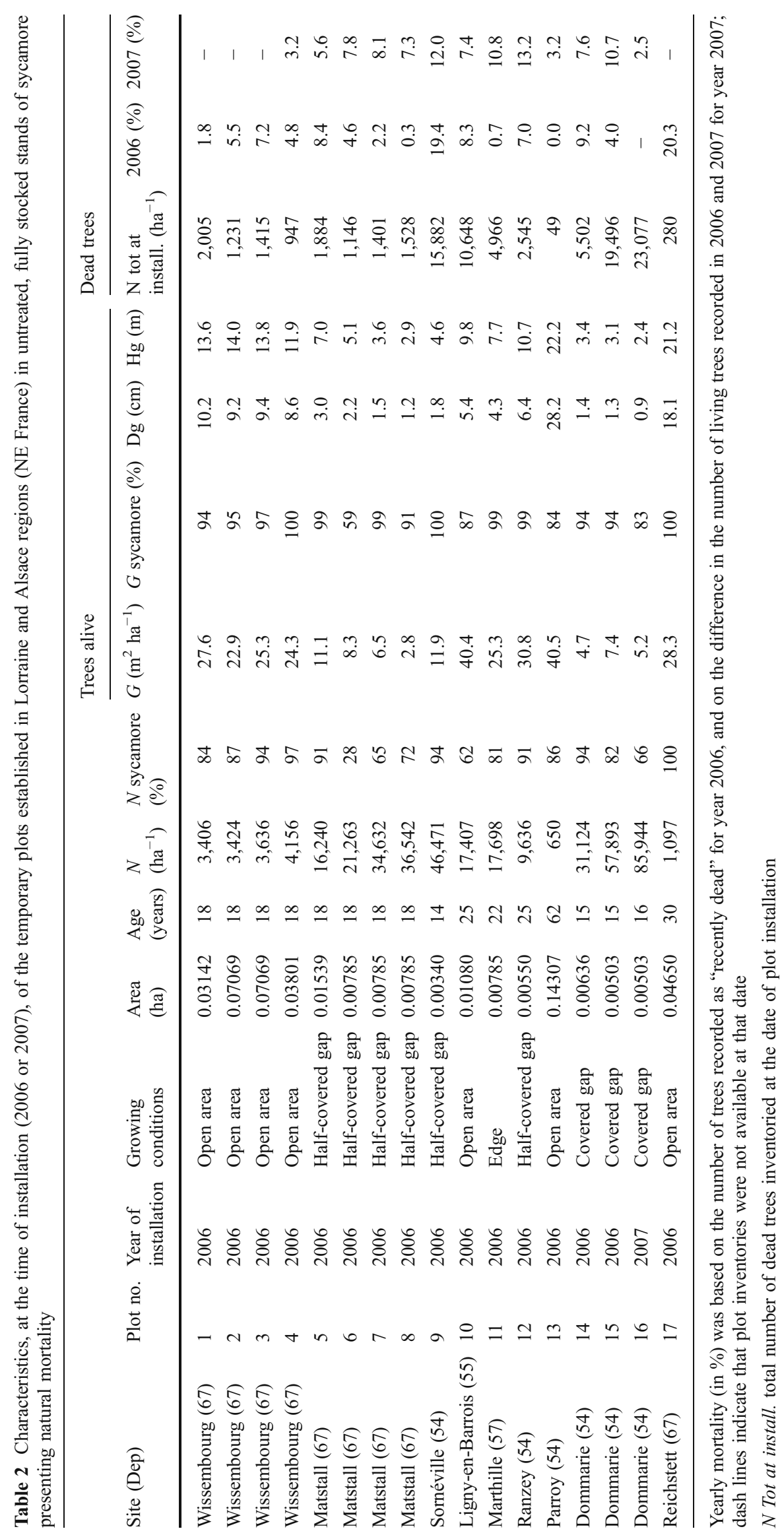


Fig. 2 Map of northern France showing the distribution of the experimental sites with selected plots (the department number is indicated on the map when it contains one or more experimental sites). The species considered - ash, beech, oak, and sycamore- are marked on the map with different symbols. The characteristics of the selected plots appear in Tables S1, S2, S3, and S4 for ash, beech, oak, and sycamore, respectively; these tables are made available as supplementary electronic material at www.afs-journal.org

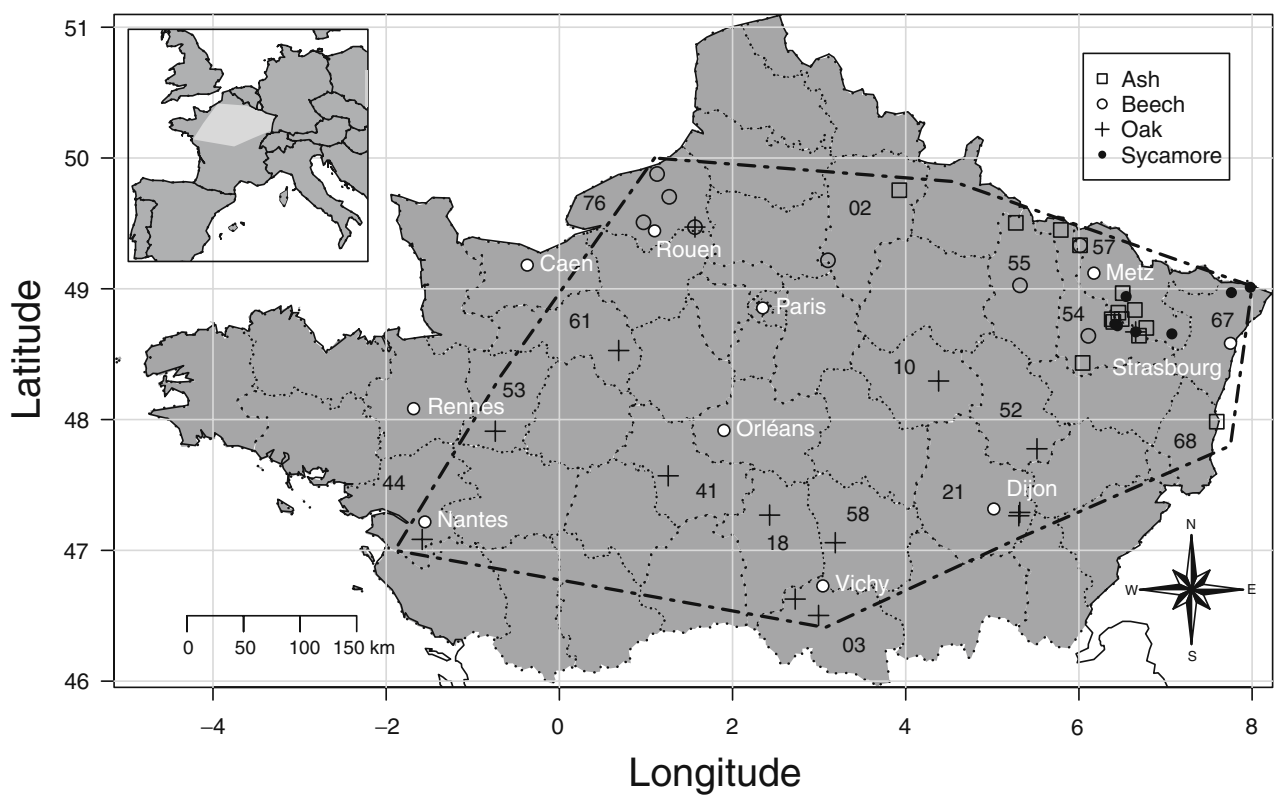

1999) was retained. It relates the number of living trees per hectare $(N)$ to their quadratic mean diameter or girth $(\mathrm{Cg})$, in the following form:

$\ln (N)=a+b \ln (C \mathrm{~g})$

where "In" stands for the natural logarithm, "a" is the intercept and "b" is the slope (negative) of the linear relation expressed by Eq. 2 .

The data finally selected for each studied species are summarized in Table 3. It shows that beech and oak plots present a much larger range of ages than ash and sycamore. Correlatively, tree girth $(\mathrm{Cg})$ reaches higher values for these two species (up to $140 \mathrm{~cm}$ for beech). Higher densities, more than 100,000 trees per ha ${ }^{-1}$, are also observed for ash, in relation with younger natural regeneration plots represented in the sample.

The factors recognized to affect the size-density relationship - Eq. (2) - were tree species and, as a whole, siteclimate interactions that we call here "stand effect". This is because for the measurements performed at the same period of time it was not always feasible to sample the stands in a way that could have allowed to distinguish between sites, and because the other stands suited for the study were measured at various periods of time with-possiblydifferent sequences of year-to-year climatic variations. Graphic and numeric statistical treatments have been carried out using the $R$ statistical environment (R Development Core Team 2009).

Using logarithmic transformations of the number of stems per hectare $(N)$ and of mean stand girth at breast height $(\mathrm{Cg})$, the relationships between the data and the factors were explored through a multistage data analysis.
For a first analysis, the transformed variables - $\ln (\mathrm{Cg})$ and $\ln (N)$-were centered by species by subtracting from each plot value the mean calculated over all plots for each species. When two variables are tied by a linear relationship, the linear equation fitted to the centered variables does not depend on their intercept, and it is a line passing through the origin with the same slope as that of the fit to the original data. In our case, the line to predict centered ln $(N)$ from centered $\ln (\mathrm{Cg})$ was fitted by a robust method well suited for data analysis (Tukey 1977). At this early stage of the analysis, a robust method was preferred to least squares, in order to avoid influences to the fit due to factors yet unaccounted for. For each species, the residual values of this fit plotted against the estimates were symmetrically distributed, showing thus clear evidence for a slope common to all species. Centered data are more or less correlated and not well suited to parametric tests, so notched boxplots (Fig. 3) were used to assess that the medians of the residuals for each species were essentially equal to zero (McGill et al. 1978), as it is the case when the notches surrounding the medians - which provide a $95 \%$ confidence interval - include 0 . Incidentally, an analysis of variance based on the $F$ test, ${ }^{5}$ which is reputed to be robust (Scheffé 1959), gave the same result $(P=0.40)$. It was then postulated that the possible differences between the linear size-density relationships for each species were due to the intercepts.

At this point, the analysis was shifted to the original logtransformed data without centering. The following linear

\footnotetext{
${ }^{5}$ At this early stage of the study, this test should be rather considered as part of the descriptive statistics that helped to set-up the statistical hypothesis framework.
} 
Table 3 Description of stand characteristics for the sample plots and inventory years finally retained for each species, and corresponding total number of observations

\begin{tabular}{|c|c|c|c|c|}
\hline \multirow[t]{2}{*}{ Variable } & \multicolumn{4}{|l|}{ Species } \\
\hline & Beech & Ash & Oak & Sycamore \\
\hline \multicolumn{5}{|l|}{ Age } \\
\hline Min & 16 & 7 & 11 & 14 \\
\hline $\operatorname{Max}$ & 134 & 70 & 117 & 63 \\
\hline Mean & 55 & 22 & 38 & 25 \\
\hline $\mathrm{SD}$ & 32.2 & 15.5 & 21.4 & 15.6 \\
\hline \multicolumn{5}{|l|}{$\mathrm{N}\left(\mathrm{ha}^{-1}\right)$} \\
\hline Min & 336 & 1,104 & 432 & 629 \\
\hline Max & 73,589 & 121,666 & 54,444 & 46,471 \\
\hline Mean & 9,777 & 39,680 & 6,559 & 11,740 \\
\hline $\mathrm{SD}$ & 16,411 & 33,908 & 8,146 & 14,203 \\
\hline \multicolumn{5}{|l|}{$G\left(\mathrm{~m}^{2} \mathrm{ha}^{-1}\right)$} \\
\hline Min & 13.12 & 7.50 & 13.59 & 11.14 \\
\hline Max & 64.53 & 47.93 & 46.42 & 40.51 \\
\hline Mean & 36.52 & 22.33 & 26.78 & 26.12 \\
\hline SD & 13.27 & 9.88 & 6.40 & 8.90 \\
\hline \multicolumn{5}{|l|}{$\mathrm{Cg}(\mathrm{cm})$} \\
\hline Min & 4.8 & 2.9 & 5.6 & 5.7 \\
\hline Max & 140.6 & 64.7 & 101.0 & 89.9 \\
\hline Mean & 56.0 & 16.7 & 32.4 & 31.6 \\
\hline SD & 38.6 & 16.7 & 17.6 & 26.6 \\
\hline $\mathrm{Nb}$ of data $(\mathrm{Cg}, N)$ & 108 & 67 & 73 & 15 \\
\hline
\end{tabular}

relationship was fitted by linear least squares to account for possible variation of the intercepts across the species:

$\ln N_{i j k}=a+a_{a} I_{a_{i j k}}+a_{o} I_{o i j k}+a_{s} I_{s_{i j k}}+b \ln C \mathrm{~g}_{i j k}$

where:

- $a_{a}, a_{o}$, and $a_{s}$ are the differential intercept values for ash, oak, and sycamore, respectively, relative to the beech intercept $a$

- $\quad i, j$, and $k$ are respectively for species, stand, and year

- $\ln N$ is the natural logarithm of number of stems per hectare

- $\ln C g$ is the natural logarithm of mean stand girth in $\mathrm{cm}$

- $I_{\text {species, }}$, with "species" $=a$ for ash, $o$ for oak and $s$ for sycamore, is the indicator-or dummy_variable for the corresponding species, which takes value 1 if the stand concerns this species and 0 otherwise.

But, as a careful examination ${ }^{6}$ of the residuals by stand showed biases, it became evident that a mixed effects model was necessary to account for unexplained stand

\footnotetext{
${ }^{6}$ This examination allowed also to locate nine outliers corresponding to first inventories in stands with repeated measures: the corresponding data were discarded as they probably reveal that stands were not yet at maximum density at the time of this early inventory.
}

effects in the intercept and slope coefficients ( $a$ and $b$, respectively) of Eq. 3. The final model to consider, including error terms, was then the following:

$$
\begin{aligned}
\ln N_{i j k}= & a+a_{a} I_{a_{i j k}}+a_{o} I_{o_{i j k}}+a_{s} I_{s_{i j k}}+b \ln C \mathrm{~g}_{i j k}+a_{\varepsilon_{i j}} \\
& +b_{\varepsilon_{i j}} \ln C \mathrm{~g}_{i j k}+\varepsilon_{i j k}
\end{aligned}
$$

with the usual basic assumptions for mixed models, that is:

- $\quad a_{\varepsilon_{i j}}$ and $b_{\varepsilon_{i j}}$ are normally distributed random variables with:

$$
\begin{aligned}
& E\left[a_{\varepsilon_{i j}}\right]=E\left[b_{\varepsilon_{i j}}\right]=0, \operatorname{var}\left(a_{\varepsilon_{i j}}\right)=\sigma_{a}{ }^{2}, \operatorname{var}\left(b_{\varepsilon_{i j}}\right)=\sigma_{b}{ }^{2} \\
& \operatorname{cov}\left(a_{\varepsilon_{i j}}, b_{\varepsilon_{i j}}\right)=\rho, \operatorname{cov}\left(a_{\varepsilon_{i j}}, b_{\varepsilon_{i^{\prime} j^{\prime}}}\right)=0 \text { if } i \neq i^{\prime} \text { or } \mathrm{j} \neq \mathrm{j}^{\prime}
\end{aligned}
$$

- $\varepsilon_{i j k}$ are normally distributed random variables, with:

$E\left[\varepsilon_{i j k}\right]=0, \operatorname{var}\left(\varepsilon_{i j k}\right)=\sigma^{2}$,
$\operatorname{cov}\left(\varepsilon_{i j k}, \varepsilon_{i^{\prime} j^{\prime} k^{\prime}}\right)=0$, if $\mathrm{i} \neq \mathrm{i}^{\prime}$ or $\mathrm{j} \neq \mathrm{j}^{\prime}$

$\operatorname{cov}\left(\varepsilon_{i j k}, \varepsilon_{i j k^{\prime}}\right)=\phi^{\left|k-k^{\prime}\right|},-1<\phi<1$, i.e. a moving average autocorrelation of order 1 .

- $\operatorname{cov}\left(\varepsilon_{i j k}, a_{\varepsilon_{i^{\prime} j^{\prime}}}\right)=0, \operatorname{cov}\left(\varepsilon_{i j k}, b_{\varepsilon_{i^{\prime} j^{\prime}}}\right)=0$, for all i, j, k, i', , 


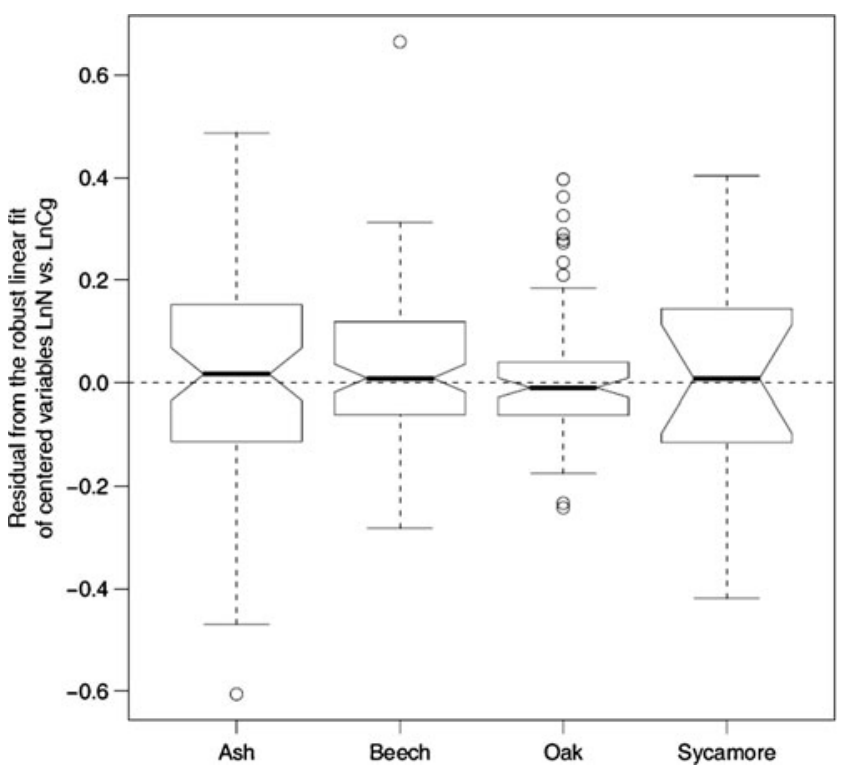

Fig. 3 Boxplots of the residuals from the robust linear fit of centered variables $L n N$ vs. $L n C g$ (if the notches about two medians do not overlap, the medians are, roughly, significantly different at about a $95 \%$ confidence level)

These assumptions, with the possible serial correlation of values observed at two successive measurement years, seem very acceptable. The package nlme (Pinheiro et al. 2009) has been used to fit and analyze this model.

It often happens, in a single experiment, that many hypotheses need to be statistically tested. Still, testing sequentially, in one context, single hypotheses at a given probability level, actually gives a higher probability of rejection of a single true hypothesis (Curran-Everett 2000). Nevertheless, as it is the case here, any individual hypothesis has most often a meaning relatively to the others, and should be considered as part of a whole, known as a family of hypotheses (Shaffer 1995). A method is then needed to guarantee a given probability of rejection of one or more single true hypothesis, while allowing to identify which one might be considered to be false. This question has been considered in the statistical literature for more than 50 years (Shaffer 1995). It is known as simultaneous inference and has received many answers in the context of analysis of variance, but for regression problems it found only recently a satisfying solution, with an implementation within the $R$ environment with the package multcomp based on the multivariate $t$-distribution (Hothorn et al. 2008; Bretz et al. 2011). Using this multiple testing procedure, the equality of the differential intercept values has been tested.

\section{Results}

Figure 4 shows the distribution of the number of stems per ha $(N)$ in relation to $\mathrm{Cg}$, in $\log -\log$ scales, for the four species considered. The data appear linearly related, as expected, and difficult to separate between species, except may be for oak for which the number of stems appears slightly lower for a given $\mathrm{Cg}$.

Equation (4) was fitted to the pooled data of ash, beech, oak and sycamore. The parameter $\phi$ of the within-stand serial correlation of the errors $\varepsilon_{i j k}$ was not statistically significantly different from 0 at any current practical preset probability level of the $x^{2}$-test associated with the likelihood ratio $(P \approx 0.68)$. This meant that we could set to 0 the parameter $\phi$, that is, we dropped the hypothesis of a withinstand autocorrelation of the errors $\varepsilon_{i j k}$, and considered them to be independent. Then, as pointed out by Pinheiro and Bates (2001), we checked the confidence intervals of the variance components to detect any problem with the model definition. Here, the ratios between the upper and the lower values of the $95 \%$ confidence intervals of the standard deviation of the random effects on the intercept and slope coefficients $\left(a_{\varepsilon_{i j}}, b_{\varepsilon_{i j}}\right)$ in Eq. (4) were respectively equal to 1.82 and 2.34 , while the same ratio for the standard deviation of the within-stand error term $\left(\varepsilon_{i j k}\right)$ was 1.34 . These values are not alarming and indicate a good model definition. This last result is in accordance with the choice of a mixed model (Pinheiro and Bates 2001, p 27).

The simple hypothesis of nullity of each coefficient obtained by fitting Eq. (4) was first tested, aiming at a descriptive view of the results of this provisional fit. As expected, the intercept $(a)$ and the slope $(b)$ were statistically significant at any current practical preset probability level of the $t$ test $(P<0.001)$. The differential intercept values for ash, oak and sycamore $-a_{a}, a_{o}$ and $a_{s}$ respectively-were not very high in absolute value, amounting between $0.6 \%$ and $0.9 \%$ of the intercept $(a)$.

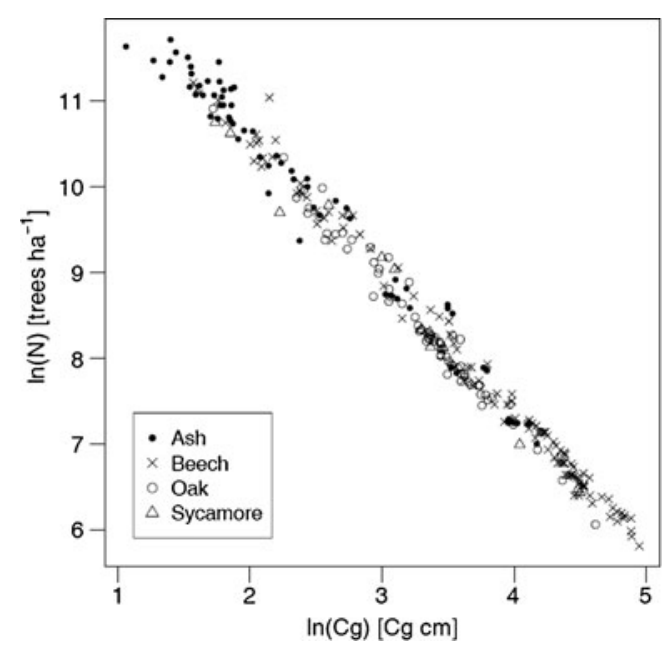

Fig. 4 The (N, Cg) data in log-log scales from selected untreated and fully stocked plots of ash, beech, oak, and sycamore 
These relatively small differential intercept values advocated for a $5 \%$ preset critical probability level in subsequent statistical tests in order to have chances to discriminate between species. At the preset $5 \%$ probability level of the $t$-test-for a single hypothesis-only the oak differential intercept value was statistically significant $(P<$ $0.005)$. The graphical analysis of the residual and standardized residual values - residuals divided by their estimated standard deviation-did not show any heteroscedasticity, and did not reflect any estimation bias. This result is summarized by a probability plot of the standardized residuals, by species, which appear very likely as standard normal probability plots (Fig. 5). The standard deviation of the random effects relative to the intercept and the slope respectively amounted to about $3 \%$ and $7 \%$ of the absolute values of the corresponding fixed effects, which was not negligible, as compared with the standard deviation of the residual error, approximately equal to 0.048 (these values advocate for the choice of a mixed model).

Then, a more formal assessment of the differences between the four species, that is testing the hypotheses that the differential intercept values differ, has been considered. The multiple statistical comparison procedure of Hothorn et al. (2008) allows to establish a critical probability level $\alpha$ for the type I error-rejection of one or more hypotheses when they are all true-and moreover to identify which contributive hypotheses are rejected. Any possible hypothesis is a linear combination

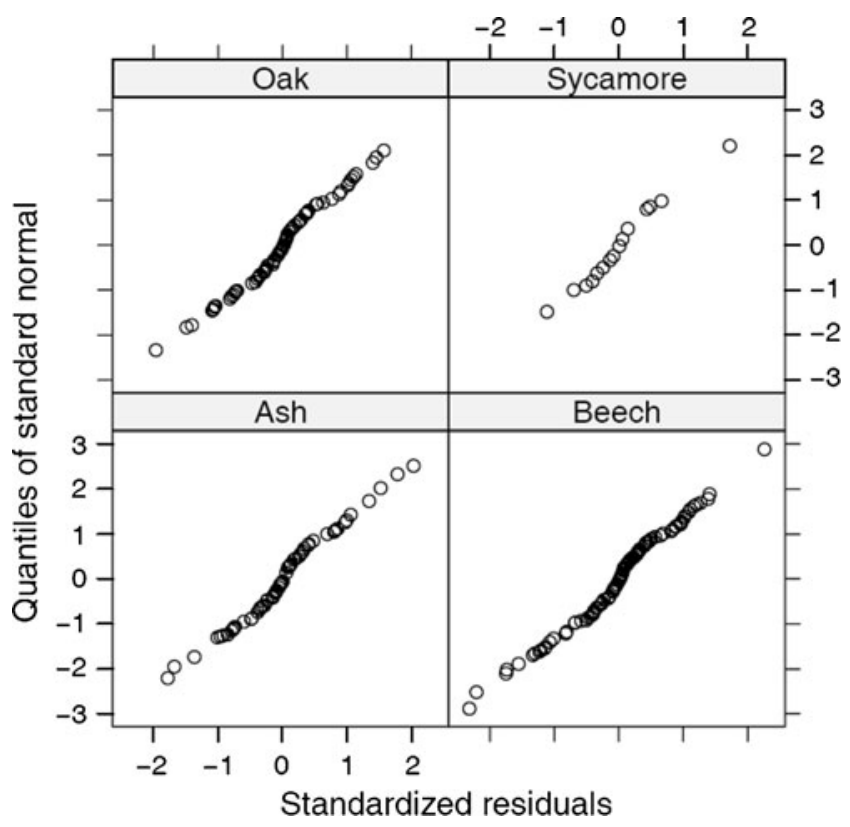

Fig. 5 Quantile-quantile plots of the residuals of the fit of Eq. 4 by species of the-fixed-parameters of the regression equation. Corresponding confidence intervals may be obtained. In our case, the values of interest were the differences between the differential intercept values of combinations of two species (that of beech being null by construction). A family-wise (Curran-Everett 2000) critical level $\alpha=$ 0.05 for a two-sided simultaneous inference test was chosen. The contributive null hypotheses of this test were obtained by equating to 0 the differences between the differential intercept values of two species. It appeared that the differences ash-oak, beech-oak, and ash-sycamore were significantly different from 0 (Fig. 6).

In the six contributive hypotheses corresponding to the possible combinations of species, five outcomes were consistent and resulted in the need for oak and sycamore of a separate size-density relationship, while ash and beech were undistinguishable from these outcomes. But, there was no statistical evidence for a difference between the differential intercept values for beech and sycamore (Fig. 6). It was eventually decided that sycamore was to share a single relationship with oak rather than with ash and beech, as the differences between the differential intercept values of oak and sycamore were closest to 0 than those of beech or ash and sycamore. We concluded that oak and sycamore needed a common separate size-density relationship, as well as ash and beech could share a common one. This result has then been taken into account to fit a model to the data where only a common oak-sycamore differential intercept value $a_{o s}$ was considered, leading to a single size-density relationship equation for ash and beech, and a separate one (with the same slope) for oak and sycamore. This model is the following:

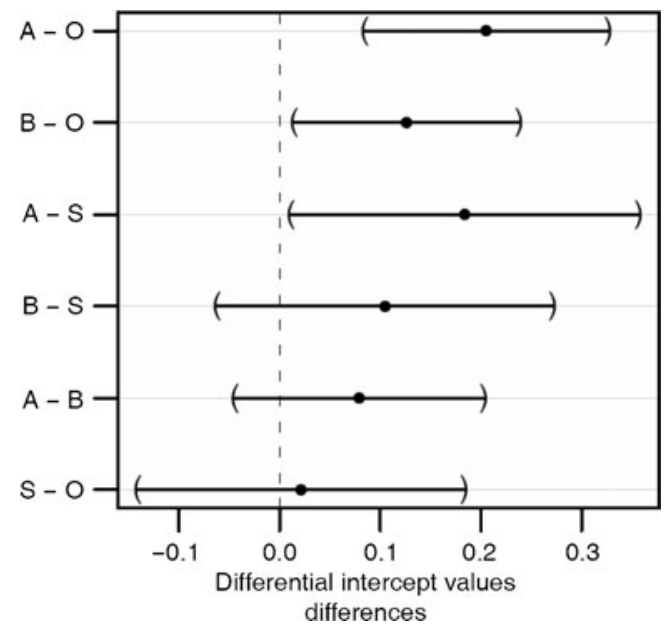

Fig. 6 Multiple 95\% confidence intervals for the differences between the differential intercept values of all combinations of two species ( $A$ ash, $B$ beech, $O$ oak, $S$ sycamore) 
Table 4 Values and statistics for the fixed coefficients of Eq. 5

\begin{tabular}{llllrl}
\hline Coefficient & Value & SE & DF & $t$ value & $p$ value \\
\hline$a$ & 13.686 & 0.060 & 143 & 228.3 & $<0.001$ \\
$b$ & -1.566 & 0.019 & 143 & -80.9 & $<0.001$ \\
$a_{o s}$ & -0.155 & 0.036 & 108 & -4.4 & $<0.001$
\end{tabular}

Correlation matrix

$\begin{array}{rcc} & a & b \\ b & -0.920 & - \\ a_{o s} & -0.039 & -0.240\end{array}$

$$
\begin{aligned}
\ln N_{i j k}= & a+a_{o s} I_{o s_{i j k}}+b \ln C g_{i j k}+a_{\varepsilon_{i j}}+b_{\varepsilon_{i j}} \ln C g_{i j k} \\
& +\varepsilon_{i j k}
\end{aligned}
$$

with the same statistical hypotheses as for the preceding model. The coefficients of the resulting size-density relationships appear in Table $4,^{7}$ the values of the fit concerning the random effects being given in Table 5 .

Two final size-density relations (Eqs. 6 and 7) result from the fit of Eq. (5) to the data:

$\ln N=13.686-1.566 \ln C g($ ash and beech $)$

$\ln N=13.531-1.566 \ln C \mathrm{~g}$ (oak and sycamore)

It is convenient to give these relations in terms of mean stand diameter $D g$ in $\mathrm{cm}$ at breast height, that is:

$\ln N=11.893-1.566 \ln \mathrm{Dg}($ ash and beech $)$

$\ln N=11.738-1.566 \ln \mathrm{Dg}($ oak and sycamore $)$

Equations 8 and 9 were inversely transformed so as to obtain the evolution of the $N$ with the $\mathrm{Dg}$ of the stand, without multiplying by the usual bias correction factor (Flewelling and Piennar 1981) which appeared here very close to 1 (1.001). It comes with the following equations:

$N=146,239 \mathrm{Dg}^{-1.566}($ ash and beech)

$N=125,242 \mathrm{Dg}^{-1.566}$ (oak and sycamore)

From Eqs. 10 and 11, it appears that oak and sycamore stands growing at maximum density have a smaller number of trees for a given $\mathrm{Dg}$, the relative difference-100 $\left(1-\exp ^{a_{o s}}\right)$-amounting to about $14.4 \%$, taking $a_{o s}$ from

\footnotetext{
${ }^{7}$ As the random effects are not formally parameters in the model, the degrees of freedom in Table IV are not simply obtained as a difference, as it is the case for fixed effects models (Pinheiro and Bates, 2001).
}

Table 4. For example, a stand of ash or beech of $40 \mathrm{~cm} \mathrm{Dg}$ can hold 453 trees per hectare that is 65 more trees per hectare than an oak or sycamore stand of the same Dg.

Stand density measures of type RDI were derived by relating the number of stems per ha $(N)$ of a given stand with mean diameter Dg to the maximum number of stems that a stand of same Dg could hold, which is given by either Eqs. 10 or 11 depending on the species considered, that is:

$\mathrm{RDI}_{a b}=\frac{N}{146,239 \mathrm{Dg}^{-1.566}}($ ash and beech $)$

$\mathrm{RDI}_{o s}=\frac{N}{125,242 \mathrm{Dg}^{-1.566}}($ oak and sycamore $)$

with Dg in centimeters.

\section{Discussion}

In this study, the self-thinning lines of the four species under concern were established on the basis of data $(\mathrm{Cg}, N)$ coming from stands at maximum density showing ongoing significant natural mortality to avoid the subjectivity in the selection of data pointed by some authors (Puettmann et al. 1993; Smith and Hann 1984). Alternative methods based on under and fully stocked stands and considering the line of maximum density as the asymptote of the whole sizedensity trajectory were developed (Tang et al. 1994; Rio et al. 2001); however, the data describing whole size-density trajectories, since the occurrence of density induced mortality, were not available for all the species considered in this study.

Nevertheless, the nature of the data sets depends on the species: data from long-term permanent plots established in unthinned stands were available for beech and oak, while data from temporary plots were mainly represented in the data sets of ash and sycamore. In this last case, additional selection criteria-mortality intensity in particular-were defined to retain only data from inventories of plots at maximum density, which contributed to reduce the data set of ash and sycamore.

Analyzing centered transformed $(\mathrm{Cg}, N)$ data, it was possible to establish that the size-density relations of the

Table 5 Values for the random coefficients obtained from the fit of Eq. 5

\begin{tabular}{lll}
\hline Coefficient & SD & Correlation \\
\hline$a_{\varepsilon_{i j}}$ & 0.392 & - \\
$b_{\varepsilon_{i j}}$ & 0.105 & -0.92 \\
$\varepsilon_{i j k}$ & 0.049 & - \\
\hline
\end{tabular}


four studied species (ash, beech, oak and sycamore) presented the same slope coefficient equal to -1.566 - very close to the one obtained by Reineke $(-1.605)$. Concerning the intercepts, the multiple comparison procedure performed allowed to distinguish two groups of species with same intercepts, ash and beech on one side and oak and sycamore on the other side, while the intercept values of beech and sycamore appeared not statistically different. But, as the differences between the intercept values of oak and sycamore were close to 0 and those of beech and sycamore were the greatest among the non-significant differences between species, we decided for a common size-density relation for ash and beech and a separate one common to oak and sycamore. This could be confirmed in the future with new inventory data obtained from the plots already used in this study or from new plots, especially for sycamore. Then, the intercept of the size-density relation appeared slightly lower for oak and sycamore-11.74 compared with 11.89 for ash and beech, with Dg as the predicting variable - and the self-thinning line of oak and sycamore runs then parallel to, and just a little below, the self-thinning line common to beech and ash.

The common slope coefficient obtained for all four species is compatible with the ones previously established in France for beech and oak with reduced data sets especially in the young stages: -1.666 (Le Goff and Ottorini 1999) and -1.701 (Dhôte 1997) for beech and oak, respectively. The intercept coefficients obtained for beech and oak are also compatible with the ones previously found by these authors which were close to 14 for both species (with $\mathrm{Cg}$ as the predicting variable). By the way, the linearity of the size-density relations, in log-log scales, was also confirmed for all four species, even in the younger stages. These results contradict the recent findings of Schütz and Zingg (2010), but the apparent curvilinearity of the size-density relations found for beech and spruce by these authors may be due to less restrictive criteria used for selecting sample stands that may not reach maximum density although being at full closure, more especially in the younger stages. The common slope coefficient of beech and oak differs more importantly from the ones obtained by Pretzsch and Biber (2005) in Germany $(-1.77$ for beech and -1.42 for oak), falling outside the $95 \%$ confidence interval for beech and being close to the lower border of the $95 \%$ confidence interval for oak. Nevertheless, as in our study, the oak size-density line falls below the beech one for the most part of the range of mean stand diameters, due to a lower value of the intercept (10.98 for oak compared with 12.36 for beech) in the German size-density equation.

Yield stand potential could not be tested as a possible additional explicative variable of the residual variation around the size-density relations established for each of the four studied species. This would have been required to be able to identify factors responsible of yield potential variations or to sort stands according to regional differences responsible of yield potential variations, as done by Hasenauer et al. (1994). In our case, either the plots were relatively concentrated in the same geographic area (as for ash and sycamore) or their number in the different geographic areas represented varied greatly (for beech and oak).

Then, oak and sycamore stands appear able to hold a maximum number of trees of a given mean Dg lower than ash and beech stands. Actually, from Eqs. 10 and 11, it appears that the mean space $(1 / \mathrm{N})$ required by oak and sycamore trees with a given $\mathrm{Dg}$ to survive in stands at maximum density is slightly larger than the one for ash and beech trees $^{8}$ : thus, for a stand of $\mathrm{Dg}=40 \mathrm{~cm}$, the mean space required by oak and sycamore trees is equal to $25.8 \mathrm{~m}^{2}$, compared with $22.1 \mathrm{~m}^{2}$ for ash and beech trees. In the German study (Pretzsch and Biber 2005), the mean space required by oak and beech appears much larger32.4 and $31.5 \mathrm{~m}^{2}$, respectively-for stands of the same mean diameter; this may reflect the particular site conditions of the few stands considered for the building of the size-density relations in Germany.

Beech is a shade tolerant species, when ash and sycamore are intermediate and oak is a relatively intolerant one (Perrin 1963). While tolerance determines the interspecific competitive ability of trees, self-tolerance can define the ability of trees of the same species to compete (Zeide 1987), and a measure of self-tolerance is given by the slope coefficient $b$ in Eq. $2 .{ }^{9}$ The parameter $b$ being common to the four studied species, these appear to present the same self-tolerance characterized by a mortality of trees of about $1.6 \%$ for a relative increase of mean diameter of $1 \%$. This result is not so surprising as intolerant species can appear more self-tolerant than tolerant ones, as it the case with southern pines in the USA (Zeide 1987): in fact, tolerant species are more able to utilize light of lower intensity, but their canopies are also denser which limits light availability inside the canopy, the two factors acting in an opposite way on tree survival.

The size-density relations established can be used to build density diagrams for the management of even-aged stands of beech, ash, sycamore and oak, as recently done for Pinus pinaster in Portugal (Sales Luis and Fonseca 2004) and as it is usual in the US forestry (Hibbs 1987). Moreover, the derived RDI equations are more and more

\footnotetext{
$\overline{{ }^{8} \text { However, the }}$ mean space really occupied by beech trees in a stand may be a little larger, due to possible tree crown overlaps in relation with the shade tolerance habit of beech.

${ }^{9}$ By differentiating Eq. 2 and replacing $\mathrm{Cg}$ by $\mathrm{Dg}$, we obtain $b=(d N / N) /(d D g / D g)$ which measures the proportion of trees eliminated by a given increase in average diameter (Zeide, 1987).
} 
used in silvicultural experiments to define density trajectories to be tested (Dhôte 1995), and also in stand growth models to relate stand or individual growth to stand density conditions (Le Goff and Ottorini 1999; Dhôte 1996). As the size-density relation is the same for beech and ash, it can be used also to calculate and control the density of even-aged beech stands mixed with ash, at least when they are close to reach maximum density conditions, and provided that the size-density relation is not changed for one or both species when they grow in mixture.

Finally, the size-density relations established for ash, beech, and sycamore, completed with the trajectories followed by each species to reach their own limiting curve, will be part of a stand growth simulator developed to help the management of pure and mixed even-aged beech stands in France. For homogeneous pure stands, these relations can be used to control and predict stand mortality (Dhôte 1996; Monserud et al. 2005; Yang and Titus 2002). In the case of heterogeneous stands, mixed or with an irregular spacing of trees (patchy structure), size-density trajectories established for pure, homogeneous stands can help to establish the individual mortality rules required to predict stand mortality.

Acknowledgments First, we would like to thank greatly the persons who helped in providing part of the data used in this study: D. Rittie (IEC, LERFoB) for data from the INRA old oak permanent plots, I. Seynave and S. Daviller (CT-Coop, LERFoB) for data from recently installed oak permanent plots that are part of the French forest network "GIS-Coop" ("Coopérative de données sur la croissance des peuplements forestiers"), ONF (French National Forest Service) for data from the juvenile beech and oak silvicultural network. We are also indebted to ONF and CRPF institutions in the Lorraine/Alsace region, for helping to search for pure stands at maximum density, especially in young stages, in order to follow their dynamics and natural mortality in temporary plots. Their implementation in the field and their careful yearly inventory are due to R. Canta (LERFoB) assisted by F. Bordat (IEC, LERFoB). This study was part of two research projects, one funded by ONF ("ModelFor") and the other one funded by INRA ("ECOGER"). Finally, we must emphasize the constant efforts supported by the INRA institution (through presently the IEC team of the LERFoB research unit in Nancy) in the management of long-term experimental plots without which this study would not have been possible. Thanks are also due to the two anonymous reviewers who brought a careful attention to the manuscript and contributed to its improvement.

\section{References}

Bégin E, Bégin J, Bélanger L, Rivest L-P, Tremblay S (2001) Balsam fir self-thinning relationship and its constancy among different ecological regions. Can J For Res 31:950-959

Bi H, Turvey ND (1997) A method of selecting data points for fitting the maximum biomass-density line for stands undergoing selfthinning. Aust J Ecol 22:356-359

Curran-Everett D (2000) Multiple comparisons: philosophies and illustrations. Am J Physiol Regul Integr Comp Physiol 279:R1-R8
Bretz F, Hothorn T, Westfall P (2011) Multiple comparisons using R. Chapman \& Hall/CRC, Boca Raton, p 187

Dhôte J-F (1995) Définition de scénarios d'éclaircie pour le hêtre et le chêne, In "Modélisation de la croissance et de la qualité des bois", Rev. For. Fr. 47: 106-110

Dhôte J-F (1996) A model of even-aged beech stand productivity with process-based interpretations. Ann Sc For 53:1-20

Dhôte J-F (1997) Effets des éclaircies sur le diamètre dominant dans les futaies régulières de hêtre ou de chêne sessile. Rev For Fr 49:557-578

Drew TJ, Flewelling JW (1979) Stand density management: an alternative approach and its application to Douglas-fir plantations. For Sci 25:518-532

Duval A-V (1987) La régénération naturelle du Frêne (Fraxinus excelsior L.): aspects qualitatifs et quantitatifs. Mémoire de DEA, Univ. Nancy I \& U.E.R. Physique-Chimie-Biologie, 46 p. + annexes

Falcone P (1985) Structure, croissance et aspects qualitatifs des plantations de Hêtre (Fagus silvatica L.). Mémoire de stage, E.N. I.T.E.F., Doc. Int. Station de Sylviculture et de Production. INRA-Nancy n85-1, p 90

Flewelling JW, Piennar LV (1981) Multiplicative regression with lognormal errors. For Sci 27:281-289

Hasenauer H, Burkhart HE, Sterba H (1994) Variation in potential volume yield of Loblolly pine plantations. For Sci 40:162-176

Hibbs DE (1987) The self-thinning rule and red alder management. For Ecol Manage 18:273-281

Hothorn T, Bretz F, Westfall P (2008) Simultaneous inference in general parametric models. Biom J 50:346-363

Le Goff N, Ottorini J-M (1999) Effets des éclaircies sur la croissance du Hêtre. Interaction avec les facteurs climatiques. Rev For Fr 51:355-364

McGill R, Tukey JW, Larsen WA (1978) Variations of box plots. Am Stat 32:12-16

Monserud RA, Ledermann T, Sterba H (2005) Are self-thinning constraints needed in a tree-specific mortality model? For Sci 50:848-858

Nicot P (1983) Etude des exigences stationnelles, des performances de croissance, de la sylviculture et de la qualité du bois du Frêne et du Merisier dans diverses stations d'Alsace. Mémoire de 3ième année ENITEF. p 238

Ningre F, Colin F (2007) Frost damage on the terminal shoot as a risk factor of fork incidence on common beech (Fagus sylvatica L.). Ann For Sci 64:79-86

Perrin H (1963) Sylviculture, Tome 1: bases scientifiques de la Sylviculture, $2^{\text {ième }}$ édition. Ecole Nationale des Eaux et Forêts, Nancy, France, p 318

Pinheiro J, Bates D (2001) Mixed-effects models in S and S-plus. Springer, Berlin, p 528

Pinheiro J, Bates D, DebRoy S, Sarkar D, R Core team (2009) nlme: linear and nonlinear mixed effects models. $\mathrm{R}$ package version 3:1-93

Pretzsch H (2005) Stand density and growth of Norway spruce (Picea abies L. Karst.) and European beech (Fagus sylvatica L.): evidence from long term experimental plots. Eur J For Res 124:193-205

Pretzsch H (2006) Species-specific allometric scaling under selfthinning: evidence from long-term plots in forest stands. Oecologia 146:572-583

Pretzsch H, Biber P (2005) A re-evaluation of Reineke's rule and stand density index. For Sci 51:304-319

Puettmann KJ, Hann DW, Hibbs DE (1993) Evaluation of the sizedensity relationships for pure red alder and Douglas-fir stands. For Sci 39:7-27

Reineke LH (1933) Perfecting a stand-density index for even-aged forests. J Agric Res 46:627-638 
R Development Core Team (2009) R: A Language and Environment for Statistical Computing. R Foundation for Statistical Computing, Vienna, Austria. ISBN 3-900051-07-0

del Rio M, Montero G, Bravo F (2001) Analysis of diameter-density relationships and self-thinning in non-thinned even-aged Scots pine stands. For Ecol Manage 142:79-87

Sales Luis JF, Fonseca TF (2004) The allometric model in the stand density management of Pinus pinaster Ait. in Portugal. Ann For Sci 61:807-814

Scheffé H (1959) The analysis of variance. Wiley, New York, p 477

Schütz J-PH, Zingg A (2010) Improving estimations of maximal stand density by combining Reineke's size-density rule and the yield level, using the example of spruce (Picea abies (L.) Karst.) and European Beech (Fagus sylvatica L.). Ann For Sci 67(507):12

Shaffer JP (1995) Multiple hypothesis testing. Annu Rev Psychol 46:561-584

Shaw JD (2006) Reineke's Stand Density Index: where are we and where do we go from here ? In: Proceedings: Society of American Foresters 2005 National Convention, Ft. Worth, TX, 19-23 October 2005. Society of American Foresters, Bethesda, MD (published on CD-ROM)

Smith NJ, Hann DW (1984) A new analytical model based on the $-3 / 2$ power rule of self-thinning. Can J For Res 14:605-609
Smith NJ, Hann DW (1986) A growth model based on the selfthinning rule. Can J For Res 16:330-334

Tang S, Meng CH, Wang YH (1994) A growth and self-thinning model for pure even-aged stands: theory and applications. For Ecol Manage 70:67-73

Tukey JW (1977) Exploratory data analysis. Addison-Wesley, Reading, p 688

Vanclay K, Sands PJ (2009) Calibrating the self-thinning frontier. For Ecol Manage 259:81-85

Weller DE (1987) A re-evaluation of the $-3 / 2$ power rule of plant selfthinning. Ecol Monogr 57:23-43

White J, Harper JL (1970) Correlated changes in plant size and number in plant populations. $\mathrm{J}$ Ecol 58:467-485

Yang Y, Titus SJ (2002) Maximum size-density relationship for constraining individual tree mortality functions. For Ecol Manage 168:259-273

Zeide B (1987) Analysis of the $3 / 2$ power law of self-thinning. For Sci 33:517-537

Zeide B (1995) A relationship between size of trees and their number. For Ecol Manage 72:265-272

Zhang L, Bi H, Gove JH, Heath LS (2005) A comparison of alternative methods for estimating the self-thinning boundary line. Can J For Res 35:1507-1514 